\title{
Chronoleadership: The New Time Battle Is about Working in Sync with Your Biological Clock
}

\author{
Camilla Kring \\ B-Society and Super Navigators ApS, Copenhagen, Denmark
}

The time battle in the industrial society was about work time and free time. The new time battle is about working in sync with our biological clock. In the knowledge society more and more work is becoming invisible in its characteristic processes. Today, over $80 \%$ of a company's value is intangible values according to the credit rating bureau, Standard \& Poor's [1]. That means that the value in a modern company is found in knowledge, network, brands, customer relations, processes, and so on, and results in work situations that can increasingly be executed across time and space. We should therefore let people work at the right times. The new normal will be to work in sync with our inner, biological clock. How do we unlock industrial clocks in our work life and begin to work in sync with our biological clocks?

I have always been fascinated by time and the role time plays in the organization of our lives. Every society has a time system in the form of a calendar that keeps social order in society, and this order would implode if all individuals lived based on their individual systems of time [2,3]. We take the calendar for granted even though it is the result of much negotiation and many power struggles. For example, Julius Caesar implemented a calendar reform, naming July after himself. After this, emperor Augustus implemented a new reform, naming August after himself. Of course, August had to have as many days as July, because emperor Augustus was a powerful man.

In medieval times, work rhythms in the countryside were dictated by the needs of the plants and animals, and an hour in the summer was longer than an hour in winter. It was a cyclical time in which nature provided the framework for human life. There was no clock time here, and it would not have made sense to inquire

Received: July 20, 2020 Accepted: July 25, 2020

Corresponding author: Camilla Kring, PhD, B-Society and Super Navigators ApS, Amagerfaelledvej 15, 1.th, Copenhagen, Denmark.

Tel: 45-28938973, E-mail: ck@supernavigators.com

(a) This is an Open Access article distributed under the terms of the Creative Commons Attribution Non-Commercial License (https://creativecommons.org/ licenses/by-nc/4.0) which permits unrestricted non-commercial use, distribution, and reproduction in any medium, provided the original work is properly cited. about the time. Have you ever considered the origin of the word "clock"? It comes from the Medieval Latin word "clocca," which means bell. This is because man's first meeting with time was auditory. Time was something that could be heard, and the bell was what "told" time.

\section{THE BATTLE BETWEEN CLOCK TIME AND INNER TIME}

With the invention of the mechanical clock in 1283, the clock began to ring, and monks became the first to organize their lives after the clock by dividing the day into time and rituals. To the sound of the clock, monks divided the 24 hours of the day into parts: work time, study time, prayer time, meal time, and bed time [4]. Clock bells became more and more common in Europe during the 13th century. Town hall bells offered towns an audible identity by marking hours, fires, funerals, work times, meetings, and curfews. The larger the town hall tower the more powerful the town. Town hall clocks were not very precise, but people obeyed the bells, and so time discipline spread from the monasteries to the common populace. In less than 100 years, clock time defeated people's biological time. An example of this can be found in In Praise of Slowness [5], in which the Canadian journalist, Carl Honoré, describes how the temporal organization of work life changed for the population of Cologne between the years of 1374 and 1398: "In the course of one generation, people in Cologne went from never knowing with any certainty what time of day it was, to allowing a clock to dictate when they worked, how long they ate lunch, and when they went home every night."

People lost an important time battle back then; a battle that has had a large impact on the way we organize our lives today. Imagine living in Cologne in the 1300s and suddenly having to obey a town hall bell that rang when you had to work, when you should eat lunch, and when you had to return home. The person who rings the bell has the power. Who was ringing the bell? And why do we still obey noiseless clocks ringing within us? It is remarkable that 
we still organize our lives to follow the bells that disciplined our forefathers in time. As a matter of fact, our culture is still deeply rooted in the agricultural society, despite the fact that fewer and fewer people are working in the farming industry today.

\section{CHRONOLEADERSHIP}

Productivity and quality of life can be improved by letting people synchronize their work lives with their biological clocks $[4,6]$. I call it chronoleadership. Chronoleadership focuses on the optimal working times for each employee. Our differences in circadian rhythms are a great competitive advantage in knowledge-based society, where technological developments and globalization make it possible as well as necessary to work at different times. I recommend that you work with chronoleadership in following areas:

- Global work. Match circadian clocks with time zone work. As a part of a globalized world, we need people in Europe who can communicate with Chinese businesses early in the morning and American businesses late in the evening.

- Team work. Visualize your team's work rhythms. I have worked with team's who discovered that they were active 22 of the 24 hours in the day [4]. By making our work hours visible, we can create more efficient teams where we work together or individually when our energy levels peak. It does not make sense for A-persons to take phone meetings in the evening, and it is unproductive for B-persons to meet at 8 A.M.

- Shift work. With respect to shift team work, it makes sense to plan work hours to match the circadian rhythms of the employee. Give A-persons more day shifts and B-persons more evening shifts.

- Working 24/7. Create sustainable working hours. We need people who work around the clock any time of year-without burning out.

Acknowledgments

Camilla Kring has a background in engineering and a $\mathrm{PhD}$ in
Work-Life Balance from Technical University of Denmark. Camilla is the founder of the consultancy firm, Super Navigators ApS (www.supernavigators.com), where the goal is to create attractive workplaces that unify quality of life and productivity. With the concept Life Navigation, Camilla transforms corporate culture by empowering employees to take control of their work and personal lives. Life Navigation has been implemented in organizations in 17 countries, and the customers are consistently rated as among the best workplaces in the world. Camilla is also the founder of the B-Society (www.b-society.org). Societies prize early risers, but most of us are late risers (B-persons). The mission of the B-Society is to increase the quality of life and productivity of B-persons by creating later starting times in schools and workplaces. B-Society has members in 50 countries.

\section{Conflicts of Interest}

The author has no potential conflicts of interest to disclose.

\section{ORCID iD}

Camilla Kring (D)

https://orcid.org/0000-0002-1508-6180

\section{REFERENCES}

1. Ocean Tomo. Intangible asset market value study. Available at: http://www. oceantomo.com/intangible-asset-market-value-study/. Accessed Jul 15, 2020.

2. Asplund J. Tid, rum, individ och kollektiv. Stockholm: LiberFörlag; 1983.

3. Hall ET. The dance of life: the other dimension of time. New York: Anchor; 1983.

4. Kring C. Life navigation-tools to improve your work-life balance. Copenhagen: Super Navigators; 2017.

5. Honoré C. In praise of slowness: challenging the cult of speed. San Francisco: HarperOne; 2004.

6. Wittmann M, Dinich J, Merrow M, Roenneberg T. Social jetlag: misalignment of biological and social time. Chronobiol Int 2006;23:497-509. 